Pamiętnik Literacki 2014, 2, s. 159-164
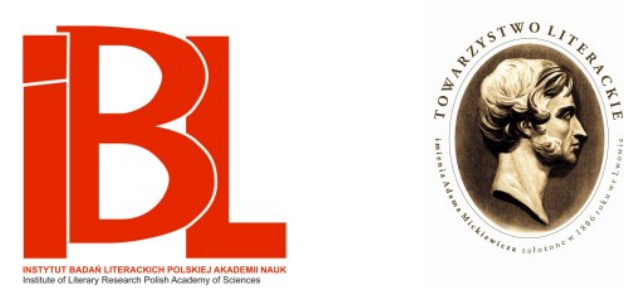

\title{
Poleskie sonety Benedykta Jankowskiego
}

\author{
Do druku podał Anton Franciszek Bryl
}

\author{
Aneks \\ O publikacji sonetów Benedykta Jankowskiego
}

Adam Pomorski 


\title{
POLESKIE SONETY BENEDYKTA JANKOWSKIEGO
}

\author{
Do druku podał \\ ANTON FRANCISZEK BRYL
}

Rękopis, który zawiera sonety Benedykta Jankowskiego ${ }^{1}$, przechowywany jest w zbiorach Biblioteki Litewskiej Akademii Nauk. Wcześniej znajdował się, jak świadczą sygnatury katalogowe, w Wileńskiej Bibliotece Publicznej.

Zeszyt in folio, bez oprawy, karty wystrzępione; papier poźółkły, atrament ciemnobrąowy, pismo staranne. Po porównaniu $z$ listami autora (o nich dalej) można stwierdzić, iż manuskrypt wyszedł spod innej ręki, a zatem to kopia, możliwe, iż wykonana specjalnie na potrzeby cenzury.

Karta tytułowa, a w ślad za nią katalog informują, że manuskrypt obejmuje „Czary. Fantazję dramatyczna $w$ dwóch częściach przez Benedykta Jankowskiego” i że 7 lutego (starego stylu) 1857 druku owej fantazji zabroniła cenzura duchowna. Potwierdza to protokół z kolejnego posiedzenia Komitetu Cenzury $^{2}$.

Fantazję otwiera Prolog na Polesiu - zacytujmy jego początek:

Cicho, cicho - i noc głucha,

Wiatr opuścił swoje żagle,

Nad przestrzenia stał i słucha...

Coś przeczuwa, dysze nagle.

Duchy ziemskie liść kołyszą,

Jak marzenia duszę we śnie;

Anioł czuwa nad ta cisza,

Lecz spogląda cóś boleśnie.

Wstają z grobów dawne cienie,

I upiory, piekieł mary,

Jakieś dziwy, cuda, czary,

Czy to złuda, czy wskrzeszenie...

Z tekstem Czarów zapoznałem się tylko częściowo; treść ma charakter na tyle mistyczny, że decyzja cenzury duchownej nie powinna dziwić. Bezpośrednio po ostatniej strofie Czarów („Nieraz mi we śnie staniesz przed oczy, / Wzbudzisz przeszłości obrazy; / Zadrzę przed tobą, dusza wyskoczy / I czucia zmienią się w głazy!"), oddzielony linią falistą i prostą pośrodku stronicy, na kartach 93v-96v pojawia się jednak cykl siedmiu sonetów. Każdy z nich zachowuje formę sonetową, anonsowaną w podtytule, zdarzają się wszakże odstępstwa od rygorów tego gatunku (np. liczba sylab odbiegająca od metrum 13-zgłoskowego, co można uznać za pomyłkę kopisty; oczywiste koniektury przywracają jednak zakłócony w manuskrypcie porządek wersyfikacyjny):

1) w trzecim sonecie (Wiosna) wers 14 liczy o jedną sylabę więcej niż pozostałe wersy pisane 13-zgłoskowcem;

2) piąty sonet (Orzet) ma o jedną linijkę mniej, niż wymaga 14-wersowa forma. Możliwe, że jest to wynik zamierzonego, spotykanego w historii gatunku, odstępstwa od reguły;

1 Lietuvos mokslu akademijos biblioteka [Biblioteka Litewskiej Akademii Nauk], Rankraščiu skyrius [Dział Rękopisów], F18-25.

2 LVIA (Lietuvos valstybės istorijos archyvas [Litewskie Państwowe Archiwum Historyczne]), 1240-1-131, k. 7v. 
3) w szóstym sonecie (Grób mój) wersy 4 i 14 liczbą sylab wyłamują się z 13-zgłoskowca.

Niektóre sonety są w rękopisie rozbite na zwrotki, inne - nie. Różnicę tę, ważną czy tylko przypadkową, zachowuję w publikacji.

Znalazłem dotychczas niewiele informacji o autorze prócz podanych w manuskrypcie. List z $1859 \mathrm{r}$. do drukarni Zawadzkiego, w którym Jankowski prosi o zwrócenie rękopisu, ma następujący adres zwrotny (w języku rosyjskim, choć sam list jest pisany po polsku): „Jego Błagorodiju Wieniediktu Jakowlewiczu Jankowskomu, Mogilewskoj Gub., w ujezdnyj g. Rogaczew, czeriez poczt. stancyju Dowsk, w im. Kamionku" ${ }^{3}$. Kilka lat wcześniej Jankowski pisał (również do Zawadzkiego) z Petersburga ${ }^{4}$. Nie ma żadnej pewności, czy Kamionka była miejscem jego stałego zamieszkania, czy też poeta czasowo przebywał tam $z$ jakiegoś powodu. $Z$ sonetów wyłania się postać podmiotu lirycznego jako człowieka zapewne młodego, bodaj ciężko chorego, pochodzącego raczej z rodziny drobnoszlacheckiej; bez dodatkowych informacji nie należy jednak $\mathrm{z}$ całym przekonaniem utożsamiać tej postaci $\mathrm{z}$ autorem. Pozostaje żywić nadzieję, że dalsze poszukiwania archiwalne pozwolą zyskać głębszą wiedzę o Jankowskim i jego twórczości.

Sonety podane są tu w kolejności, w jakiej umieszczono je w rękopisie. W manuskrypcie cykl nie został wyróżniony odrębnym tytułem. Na użytek niniejszej publikacji niech mi wolno będzie mówić o „poleskich sonetach” Benedykta Jankowskiego. W przytoczonych tu tekstach wprowadzam minimalne zmiany modernizacyjne w zakresie pisowni, stosowania znaków diakrytycznych („śmierć” zamiast „smierć”, „ptaków” zamiast „ptakow” itp.) oraz interpunkcji. Jako regionalizm (ewentualnie archaizm) pozostawiam jednak np. pisownię „cóś” zamiast „coś”, „spójrzałem” zamiast „,spojrzałem”, „dójda” zamiast „dojda”, ale „uniosł” zamiast „uniósł”. Charakter regionalny ma też konsekwentnie używana przez autora forma biernika w liczbie pojedynczej "go" zamiast ,je” w rodzaju nijakim, forma liczebnika ,jedne” zamiast ,jedno” - oraz zapis „dzionek-drugi”.

Dziękuję Adamowi Pomorskiemu i Hannie Jankucie, bez których pomocy przygotowanie niniejszej publikacji nie byłoby możliwe.

BENEDYKT JANKOWSKI

DO KLARY

(Sonet)

Graj mi, Klaro, niech duch mój na chwilkę utonie

W krainie marzeń - wkrótce ostatnia zadzwoni...

A w mej duszy nieprędko ogień się rozpłoni;

Łza padnie na pustyni i śmierć mię pochłonie.

Niech jeszcze się zatrzymam i ucho nastroję,

Na twych tonach ulecę w nieznaną krainę,

Usłyszę duchów pienia i życie rozwinę,

Spocznę w błogim natchnieniu, ból serca ukoję.

Tylko nie graj miłośnie, bo gdy wwięzisz ${ }^{5}$ ducha,

Myśl bezpłodna zaginie w odmęcie marzenia,

Tony zleją się w sercu i zwarza go snadnie,

A w piersi będzie wulkan, co powoli dmucha,

Nim ostatnie wyzionie $\mathrm{z}$ popiołem westchnienia; -

Jakaż otchłań okropna odkryje się na dnie!... [k. 93v]

3 Lietuvos mokslu akademijos biblioteka, Rankraščiu skyrius, F7-654, k. 3r.

4 Ibidem, k. lv.

5 Tak w rękopisie. 


\section{STRUMYK}

(Sonet)

Drzemia sosny stoletnie - u stóp strumyk płynie, Ale wody w nim czyste, choć sączy z błot zgniłych. Siadłem nad brzegiem w cichej poleskiej krainie I w wód biegu myśl topię - ach, ileż chwil miłych Zbiegło się razem w duszy!... przeszłość smutek rodzi Gardzę!... Mój strumyk wierzby objęły w ramiona Krępuja, cisna, ciemnią - on na wierzch wychodzi; Jak wąż, gdy jad wypuści - ucieka i kona...

Patrz! już się z niebem zlewa - już jak Niemen płynie;

Po nim żeglują ludzie, lecą ptaków łodzie;

Już się pyszni potęgą, inne przybrał imię...

Czemuż mi nie popłynąć? - Bóg moim wioślarzem; Padam piersią bez łodzi na czyste powodzie

I płynę - w oceanie... O, jestem żeglarzem! - [k. 94]

\section{WIOSNA}

(Sonet)

Dzionek-drugi ${ }^{6}$ i śniegi topnieją leniwie; Rzeki leżą w okowach - powoli się wzdęły, Kruszą szyby lodowe i z szumem runęły Lecą kaskady, gryzą zapory zjadliwie...

Pagórki wysunęły spod lodów łby gołe, Śmieją się jako starcy po długim więzieniu. Skowronek skrzydełkami trzepoce w sklepieniu, Słodkie trele wywodzi na tony wesołe.

Cyt! tam żurawie ciągna - siadają na niwie;

Może nam cóś zwiastują, powiedzą nowiny.

One zwiedzają różne kraje, okolice;

Mają swoje sejmiki i znają granice;

Bo nigdy nie mijają Litewskiej krainy.

Patrz! ${ }^{7}$ cóś smutne - nie krzyczą - siadają trwożliwie!... [k. 94v]

CHMURA

(Sonet)

Coraz większe nad głowa przechodzą straszydła, Leca jak piekieł mary - ponuro się wleką.

6 Zapis „dzionek-drugi” (w idiomatycznym znaczeniu 'za parę dni') zamiast naturalnego w dzisiejszej polszczyźnie „dzionek, drugi”.

7 W rękopisie: „Patrzcie!” 
Plączą, wiążą jak duchy w otchłaniach swe skrzydła,

I objęły już cały horyzont daleko.

Mdło w duszy, mdło na sercu; powietrze się sparło, Jak ołów cięży ciału - tchnie martwym wyziewem, Jedne westchnienie duszy się $z$ łona wydarło, Lecz wichr go uniosł - zabił duszącym powiewem.

Choragiewka na dachu jęknęła piskliwie, Obiegła w koło - słucha - staje - to znów leci, Jak ptak, co na uwięzi się wzrywa zdradliwie, Duch mój wzniosł się wysoko i chmury rozpycha, Drżąc nad krajem ojczystym; - lękajcie się, dzieci! Padnijcie na kolana i modlcie się $\mathrm{z}$ cicha!... [k. 95]

ORZEL

(Sonet)

Słyszę lot ptaka - gwiżdże szerokimi pióry, Zdaje się mię uderzać po sercu swym lotem; Coraz bliżej i pierś mą potrząsa jak grzmotem. Spójrzałem - nic nie widzę, tylko czarne chmury ${ }^{8}$. Wtem rozdarł chmur zawoje i stojąc w gwiazd kole, Patrzy groźnie: „O, nędzni! znosicie niedolę! Jam orzeł! jam pan świata!" - i znowu okręża... Rzekłem na to: o, gdybym miał skrzydeł tych dwoje! Przewyższyłbym w polocie i gwiazdy, i słońce! Ty byś, ptaku powietrzny, zazdrościł mej sławie. Dumał, dumał, jak gdyby zgłębiał myśli moje; Wzrokiem mierzył skwapliwie wszystkie świata końce!... Hura! hura! - krzyknęły litewskie żurawie. [k. 95v]

GRÓB MÓJ

(Sonet)

Umieram... coraz smutniej mi płyna godziny, Coraz rzadziej i wiosna uśmiecha się w duszy; Wkrótce życia ostatnia łez kroplę wysuszy, Krew ostygnie - zostaną ${ }^{9}$ spróchniałe wyżymy ${ }^{10}$.

Grabarzu! nie myśl długo, rzuć piasku i gliny Na obumarłe zwłoki, to mój pogrzeb cały; 
Nie chcę, aby mój pomnik był z muru lub skały.

Krzyż u głowach, a resztę - mogiła $z$ darniny.

Klaro! bądź zdrowa! żegnam imieniem kochanki;

Gdy w twym łonie anielskim zazieleni wiosna,

Gdy wybieżysz na łąkę ustrajać równianki ${ }^{11}$,

Może dójdą do ciebie kruka pogadanki,

Albo pierś twą poruszy pieśń wilka żałosna,

Rzuć na grób mój choć listek ręką chrzcianki! ${ }^{12}$ [k. 96]

\section{CZY PAMIETASZ?}

(Sonet do M. H.)

Pomnisz, kiedyśmy kwiatki w ogródku sadzili, Jam kopał ziemię w pocie, tyś rzucała ziarna;

Gdyśmy usiedli w cieniu na kanapie $\mathrm{z}$ darna ${ }^{13}$

I myśl nurząc w przyszłości o szczęściu mówili?...

Ileż tam złotych było obrazów i myśli,

Ile życia swobody i tkliwej rozmowy!...

Któż dziś wszystko wypowie i jakimi słowy?

Ledwie kilka odcieniów na kartę się skryśli.

Spójrz pod zasłonę czasu! - tam nasze pamiątki,

Tam myśli leżą w urnie, czekają wskrzeszenia,

Tam leży szmat papieru lub tych kwiatów szczątki[.]

Może jeszcze nie zgasła w świątyni pamięci

Lampa czystej przyjaźni, co wskrzesza wspomnienia;

Westchnij... zapomnij, bo mi łza w oczach się kręci. [k. 96v]

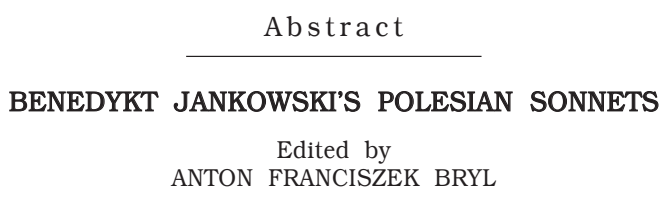

The article contains 7 sonnets by Benedykt Jankowski. The sonnets, previously unknown, come from a manuscript treasured in the Library of the Lithuanian Academy of Sciences. A mark on the manuscript informs that is was rejected by censorship authorities in 1857. All the information we have about the author comes from the manuscript itself and from two letters to the publisher, written in 1850s and preserved currently in the same library. The sonnets have no common title. The title of the present publication refers to Polesia, a historical region mentioned in one of the sonnets and in a larger dramatic work in the same manuscript, and to which the place from where one of the letters was addressed belongs.

"Rownianki" (wyraz przestrzary) to 'bukiety z kwiatów lub ziela'

„Chrzcianka” (pseudoarchaizm) - 'chrześcijanka'. Być może, jest to błąd kopisty; zamiana na 'chrześcijanki' przywróciłaby właściwą liczbę sylab.

„Darn” - męska postać słowa „darń”, używana m.in. przez J. I. Kraszewskiego. 
ANEKS

ADAM POMORSKI Warszawa

\section{O PUBLIKACJI SONETÓW BENEDYKTA JANKOWSKIEGO}

Publikacja cyklu sonetów Benedykta Jankowskiego, wydobytych z rękopisu i z niebytu przez Antona Franciszka Bryla - białoruskiego poetę i filologa, najmłodszego przedstawiciela wielce zasłużonej w kulturze białoruskiej rodziny, licznymi nićmi związanej też z Polską - warta jest uwagi z kilku względów. Po pierwsze, o owym Benedykcie Jankowskim nikt dotąd nie słyszał: nie notuja jego nazwiska ani Nowy Korbut, ani Polski słownik biograficzny, ani Zbiór poetów polskich XIX wieku Pawła Hertza - niezastąpiony w upamiętnieniu również prowincjonalnych rymopisów. Po drugie jednak, autor sonetów - mimo widocznych cech twórczości nieprofesjonalnej - miarą talentu nawet w kalekiej kopii rękopiśmiennej (najwidoczniej pochodzącej ze zbiorów cenzury) zdaje się przerastać byle rymopisa oczytanego tyleż w sonetach Mickiewicza, ile w popularnych w epoce rosyjskich wierszach, dajmy na to, Benediktowa. To nie tylko dyletant, hołdujący spóźnionej modzie tzw. wulgarnego bajronizmu: dość spojrzeć na najlepszy w publikowanym cyklu sonet Chmura. Nie jest to też, po trzecie, przypadek amatorszczyzny prowincjonalnej - Wilno było wtedy (w r. 1857, a właściwie w 1856, zważywszy datę cenzuralnego zakazu: luty 1857) ośrodkiem kulturalnym i edukacyjnym żywszym niż po-Paskiewiczowska jeszcze Warszawa. Tymczasem klęska Rosji w wojnie krymskiej, śmierć Mikołaja I, idące z Petersburga pierwsze podmuchy zbliżającej się odwilży politycznej i wielkiej epoki reform wkrótce wzbudzić miały ferment także na zachodnich rubieżach Imperium. Zanim więc o dorobku początkującego poety Benedykta Jankowskiego wyda się dzisiaj sąd, trzeba sprawdzić jego usytuowanie na ówczesnej mapie kulturalnej i ustalić przynajmniej podstawowe dane biograficzne: daty życia, miejsce zamieszkania, przynależność narodową i społeczną, związki rodzinne i polityczne (jak się on ma np. do Placyda Jankowskiego - piszącego po polsku Białorusina $z$ koterii petersburskiej?), okoliczności śmierci - nie zapominajmy o nieodległym kataklizmie r. 1863 na Litwie. Młodemu białoruskiemu poecie, który przywraca to zapoznane półtora wieku temu nazwisko kulturze polskiej, należą się wyrazy wdzięczności i szacunku. 